\title{
Analisis Unjuk Kerja Motor Induksi 3 Fasa Menggunakan Inverter 3 Fasa
}

\author{
Yogi Pranata $^{1}$, Teguh Arfianto ${ }^{2}$, Nandang Taryana ${ }^{3}$ \\ $1,2,3$ Institut Teknologi Nasional \\ 1,2,3 Jalan PH.H. Mustofa No.23 Bandung \\ yogipranata51@yahoo.com ${ }^{1}$, teguh.arfianto@gmail.com ${ }^{2}$, yanztar17@gmail.com ${ }^{3}$
}

\begin{abstract}
Abstrak - Variabel speed drive adalah alat yang digunakan untuk mengatur kecepatan motor induksi 3 fasa, dengan cara mengatur frekuensi yang akan diberikan kepada motor induksi. Pengaturan frekuensi pada inverter bertujuan untuk melakukan penghematan daya dikarenakan pengaturan frekuensi berbanding lurus dengan pengaturan tegangan. Untuk mendapatkan nilai hasil penghematan daya menggunakan inverter, akan dilakukan pengujian pengaturan kecepatan motor menggunakan inverter dengan motor pompa agar debitnya bisa diatur dengan mengatur kecepatan putaran motor, debit yang diatur saat menggunakan inverter dayanya akan dibandingkan dengan pengaturan debit menggunakan throttle. Selisih daya yang dibutuhkan untuk mengeluarkan debit yang sama menunjukan hasil penghematan energinya. Pengujian menggunakan throttle dengan debit fix yang keluarannya diatur pada putaran valve. Pengaturan debit menggunakan inverter dengan mengatur kecepatan putar motor dengan cara mengatur frekuensinya. Nilai selisih penggunaan daya adalah efisiensi penghematan dayanya. Hasil dari percobaan yang dilakukan, nilai penghematan dayanya sebesar 369,8 kWh/hari.
\end{abstract}

Kata kunci: Variabel speed drive, Motor induksi, Frekuensi dan daya

\section{Pendahuluan}

Motor induksi adalah motor listrik arus bolak-balik yang paling banyak digunakan. Tetapi terdapat kelemahan pada motor induksi, yaitu sulitnya mengendalikan kecepatan. Langkah yang dapat dilakukan untuk mengatur kecepatan motor induksi yaitu dengan mengubah frekuensi yang masuk pada motor induksi. Mengubah frekuensi pada motor induksi juga berpengaruh pada daya yang dibutuhkan pada motor, semakin kecil frekuensi semakin kecil juga daya yang dibutuhkan. Jadi secara tidak langsung mengatur frekuensi dapat menghemat pemakaian daya. Alat yang dapat mengatur frekuensi pada motor induksi dinamakan dengan variabel speed drive. Riset dan pengujian penghematan daya menggunakan throttle dan menggunakan inverter Variable Speed Drive (VSD), maka perlu ditetapkan referensi dan standar mengenai bentuk kerja inverter VSD.

Analisis unjuk kerja motor induksi 3 fasa menggunakan inverter VSD 3 Fasa. Hal ini ditujukan untuk mengetahui kurva penghematan daya terhadap debit dengan menggunakan inverter VSD dalam kondisi debit dijaga fix dengan pengaturan throttle (katup). Kurva yang sudah diketahui dapat mengetahui efisiensi penghematan daya dengan menggunakan inverter dan menggunakan throttle. Pada penelitian ini digunakan metode perbandingan debit pada VSD dan throttle. Oleh sebab itu dalam makalah ini alat yang dibuat ditujukan sebagai alat uji efisiensi penghematan daya dengan menggunakan inverter VSD dan menggunakan throttle, Selanjutnya alat tersebut dapat dikembangkan lagi bukan hanya sebagai alat uji.

Pengasutan motor listrik dengan metode start-delta dapat mengurangi lonjakan arus

TELKA, Vol.4, No.2, November 2018, pp. 91 102

ISSN (e): 2540-9123

ISSN (p): 2502-1982 
starting hingga 1/3 kalinya, namun dengan frekuensi start-stop yang tinggi dapat menyebabkan pemborosan energi. Dalam hal penghematan energi, VSD digunakan sebagai softstarter yang dapat mengurangi besarnya lonjakan arus starting dengan pengaturan timing acceleration dan kecepatan putar motor pada saat starting. Penggunakan variable speed drive dalam penelitian ini dapat mereduksi biaya sebesar 49,51\% atau Rp. 2.246.109,36 dalam sebulan (Ria Prasetyo).

Analisis energi listrik merupakan upaya untuk mengoptimalkan kerja peralatan pada kondisi beban penuh sehingga penggunaan energi listrik menjadi lebih efektif, efesien dan rasional tanpa harus mengurangi kinerja produksi dan bertujuan untuk mendapatkan informasi mengenai tingkat konsumsi energi yang di gunakan per satuan output (produksi) serta mengindentifikasi peluang penghematan energi listrik.

Penelitian ini menggunakan VSD (variable speed drive) yang berguna sebagai pengatur kecepatan pada motor dan juga dengan melakukan pengukuran serta perhitungan intensitas kebutuhan energi (IKE) 115,21 kwh/ton, untuk dihasilkan penghematan biaya yang diinginkan serta indentifikasi peluang penghematan dilakukan setelah analisis perilaku dan kinerja beban. Hal yang didapat adalah penghematan energi listrik sebesar $28-60 \%$ pada motor listrik, total penghematan energi listrik adalah 4,95\%, atau sama dengan 43.149,6 kwh/bulan, atau bila dirupiahkan sama dengan Rp 343.412.232 /tahun (Iwan Abdul Malik).

\section{Metoda Penelitian}

Metode penelitian merupakan langkah-langkah yang akan dilakukan dalam penelitian. Langkah-langkah ini saling berkaitansatu dengan yang lain dan berurutan. Langkah-langkah penelitian dapat dilihat pada Gambar 1.

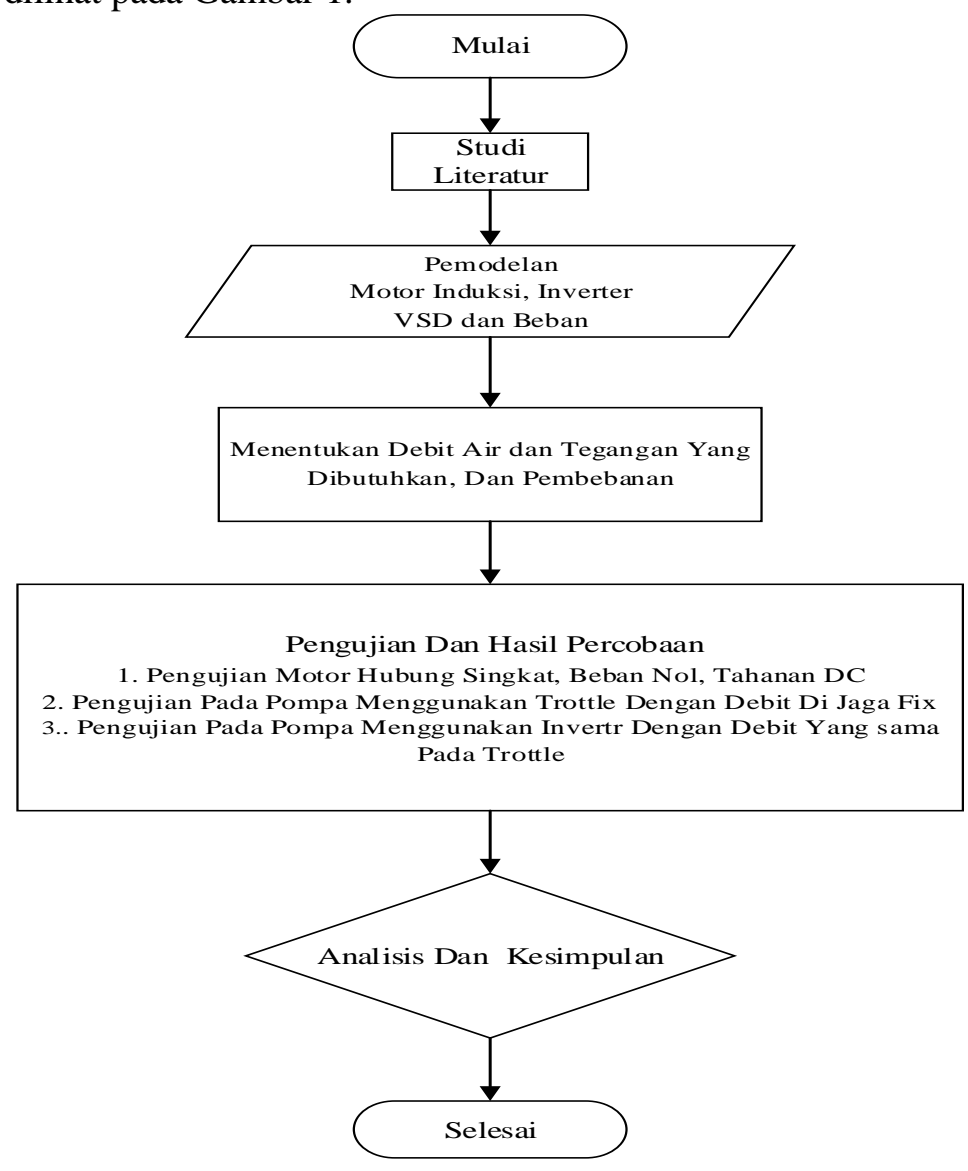

Gambar 1. Flowchart Kerja

ISSN (e): 2540-9123

ISSN (p): 2502-1982 


\subsection{Diagram Block Pengujian}

Diagram block pengujian merupakan urutan sistem yang dilakukan dalam pengujian. Sistem pengujian ini bertujuan untuk mengetahui nilai keluaran variabel speed yang diuji yaitu kecepatan motor, $\cos \boldsymbol{\emptyset}$, debit air dan daya yang dibutuhkan.

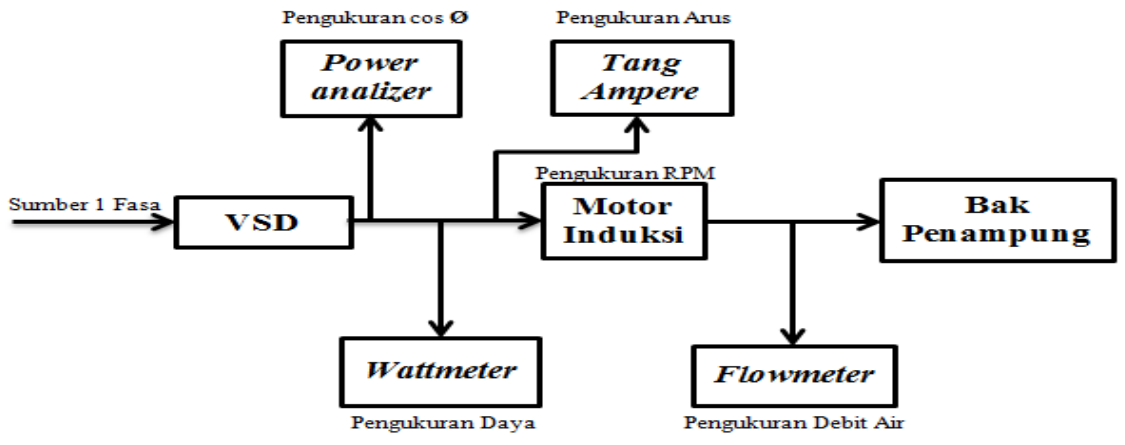

Gambar 2. Diagram Blok Pengujian

\subsection{Pemodelan Sistem}

Pemodelan pada Gambar 3 merupakan bentuk dari proses melakukan pengujian pada motor induksi dan inverter. Pemodelan sistem ini bertujuan untuk mengetahui parameter-parameter apa saja yang dibutuhkan dalam proses pengujian.

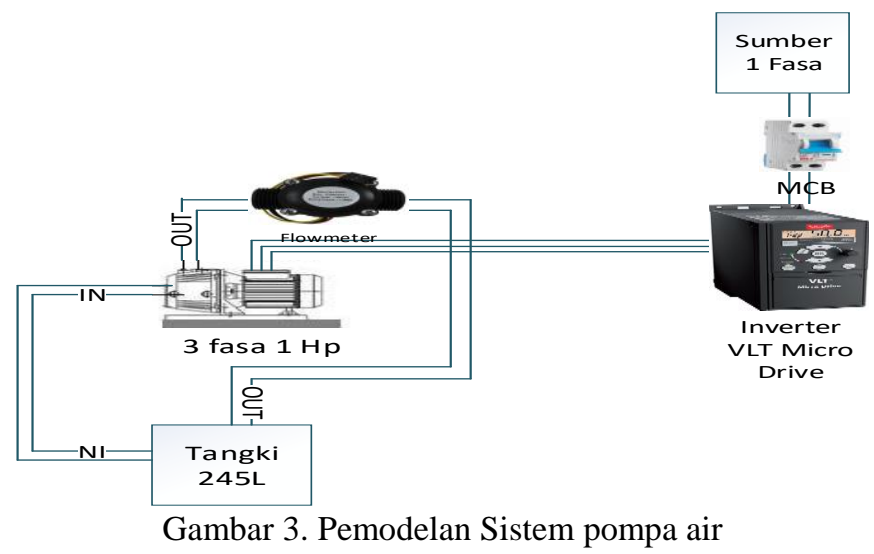

A. Desain tangki yang akan digunakan pada penelitian adalah tangki dengan kapasitas 245 Liter yang terdiri dari:

$$
\begin{aligned}
& \mathrm{P}=0,7 \mathrm{~m} \\
& \mathrm{~L}=0,5 \mathrm{~m} \\
& \mathrm{~T}=0,7 \mathrm{~m} \\
& \mathrm{~V}_{\text {tangki }}=0,7 \cdot 0,5 \cdot 0,7 \\
& =0,245 \mathrm{~m}^{3} \\
& =245 \text { Liter }
\end{aligned}
$$

B. Pada pengujian, digunakan debit maksimum yaitu $56 \mathrm{~L} / \mathrm{m}$ dalam kurun waktu sekali percobaan selama 60 menit.

$$
t=\frac{245}{56}=4,375 \text { menit }
$$

Pengujian yang akan dilakukan dalam satu kali percobaan di debit maksimum $56 \mathrm{~L} / \mathrm{m}$ adalah dalam kurun waktu 60 menit.

C. Untuk mengatahui seberapa besar daya pada pompa, sebelumnya harus diketahui parameterparameter yang terdapat pada motor pompa itu sendiri, seperti debit dan ketinggian head pompa. Dari sistem yang digunakan, didapat parameter-parameter:

$$
\begin{array}{llll}
\mathrm{Q} & =56 \mathrm{~L} / \mathrm{m} & \mathrm{L} & =3 \mathrm{~m} \\
\mathrm{H}_{\max } & =0,8 \mathrm{~m} & \mathrm{e} & =5 \mathrm{buah}
\end{array}
$$




$$
\begin{aligned}
\mathrm{H}_{\mathrm{L} \text { mayor }} & =f \cdot \frac{L}{D} \cdot \frac{V^{2}}{2 g} \\
& =\frac{64}{R e} \cdot \frac{3}{0,038} \cdot \frac{V^{2}}{2 \cdot 9,81} \\
& =\frac{64}{\frac{\rho \cdot\left(\frac{\pi}{4}+D^{2}\right) \cdot D}{\mu}} \cdot \frac{3}{0,038} \cdot \frac{\left(\frac{\pi}{4} \cdot D^{2}\right)^{2}}{2 \cdot 9,81} \\
& =\frac{64}{\frac{1000 \cdot \frac{3,14}{4}+0,038^{2} \cdot 0,038}{0,001}} \cdot \frac{3}{0,038} \cdot \frac{\frac{3.14}{4} \cdot 0,038^{2}}{2 \cdot 9,81} \\
& =0,1277 \cdot 78,94 \cdot 0,031 \\
& =0,31 \mathrm{~m} \\
\mathrm{H}_{\mathrm{L} \text { minor }} & =\sum f \cdot \frac{L e}{D}+\frac{V^{2}}{2 g} \\
& =5 \cdot[0,027 \cdot 0,1277+0,031] \\
& =0,17 \mathrm{~m} \\
\mathrm{H}_{\mathrm{L} \text { total }} & =\mathrm{H}_{\max }-\left(\mathrm{H}_{\mathrm{L} \text { mayor }}+\mathrm{H}_{\mathrm{L} \text { minor }}\right. \\
& =0,8+(0,31+0,17) \\
& =1,28 \mathrm{~m}
\end{aligned}
$$

Untuk mengetahui nilai daya maksimum yang akan dihitung dilakukan dengan menentukan debit maksimum yaitu $56 \mathrm{~L} / \mathrm{m}$, agar kita dapat menentukan motor pompa tipe apa yang digunakan.

$$
\begin{aligned}
\mathrm{P}_{\text {pompa }} & =\rho \cdot g \cdot Q \cdot H \\
& =988 \cdot 9,81 \cdot 0,056 \cdot 1,28 \\
& =702 \mathrm{w}
\end{aligned}
$$

Pemilihan motor indduksi 3 fasa $1 \mathrm{Hp}$ karena kapasitas dayanya mendekati dari nilai perhitungan yang dilakukan dengan debit air maksimum.

\subsection{Menentukan Debit Air dan Tegangan Yang Dibutuhkan, Dan Pembebanan Serta Gangguan.}

Pada tahapan ini sebelum melakukan pengujian pada motor pompa menggunakan throttle dan menggunakan inverter, harus ditentukan seberapa besar debit air dan tegangan yang dibutuhkan, dan pembebanan yang akan diberikan pada percobaan throttle dan pada inverter pada motor pompa.

Pada pengujian yang dilakukan, sebelumnya harus memberikan parameter-parameter debit air dan tegangan yang di butuhkan, dan pembebanan yang akan diberikan.

Tabel 1. Parameter-Parameter Debit Dan Tegangan

\begin{tabular}{|c|}
\hline Pengujian Throttle Dan Inverter \\
\hline Q (L/m) \\
\hline 56 \\
\hline 47 \\
\hline 36 \\
\hline 24 \\
\hline 10 \\
\hline
\end{tabular}

Menentukan parameter-parameter ini bertujuan untuk membandingkan nilai efisiensi penghematan energy menggunakan throttle dan menggunakan inverter. 


\subsection{Percobaan Motor Induksi 3 Fasa Menggunakan Inverter VSD 3 Fasa.}

\section{A. Motor Induksi 3 Fasa}

Didapatkan persamaan untuk mengetahui kecepatan sinkron dari motor:

$$
\begin{aligned}
& n_{s}=\frac{120 . f}{P}=\frac{120.50}{4}=1500 \mathrm{rpm} \\
& \omega_{s}=n_{s} \cdot\left(\frac{2 \pi \mathrm{rad}}{1 \mathrm{r}}\right) \cdot\left(\frac{1 \mathrm{~min}}{60}\right)=3000 \mathrm{rpm} \cdot 2 \pi \cdot\left(\frac{1}{60}\right)=314 \mathrm{rad} / \mathrm{s}
\end{aligned}
$$

Berdasarkan persamaannya nilai slip pada saat mendekati kecepatan sinkron, sebagai berikut:

$$
\text { Slip }=\frac{n_{s}-n_{r}}{n_{s}} \times 100 \%
$$

\section{B. Pengujian Tanpa Beban (No Load Test)}

Didapatkam persamaan untuk mengetahui impedansi beban nol, hambatan beban nol, dan slip pada beban nol:

$$
\begin{aligned}
& Z_{n l}=\frac{V_{n l}}{I_{n l}}(\Omega) \\
& R_{n l}=\frac{V_{n l}^{2}}{P_{n l}}(\Omega) \\
& \text { Slip }=\frac{n_{s}-n_{r}}{n_{s}} \times 100 \%
\end{aligned}
$$

\section{Pengujian Hubung Singkat}

Didapatkam persamaan untuk mengetahui impedansi beban hubung singkat dan, hambatan hubung singkat:

$$
\begin{aligned}
& Z_{L R}=\frac{V_{L R}}{I_{L R}} \\
& R_{L R}=\frac{V_{L R}{ }^{2}}{P_{L R}}
\end{aligned}
$$

Pada perhitungan torsi dari pompa ini, Pout adalah daya keluaran pada pompa yang telah di hitung dengan mengurangi Pin motor dengan rugi-rugi yang terdapat pada motor. Pada $\omega s$ dapat diketahui dengan cara menghitung, dengan rumus: 


$$
\omega_{s}=n_{s} \cdot\left(\frac{2 \pi \mathrm{rad}}{1 \mathrm{r}}\right) \cdot\left(\frac{1 \mathrm{~min}}{60}\right)=3000 \mathrm{rpm} \cdot 2 \pi \cdot\left(\frac{1}{60}\right)=314 \mathrm{rad} / \mathrm{s}
$$

\subsection{Menghitung Daya Outpot Motor Listrik 3 Fasa}

Merupakan bentuk proses perhitungan untuk mengetahui nilai daya keluaran yang akan dihasilkan pada motor induksi dengan cara Pin pada motor induksi dikurangi nilai rugi-rugi disetiap komponen pada motor induksi, setelah Pin dikurangi nilai rugi-rugi pada motor induksi diketahuilah nilai Pout pada motor induksi.

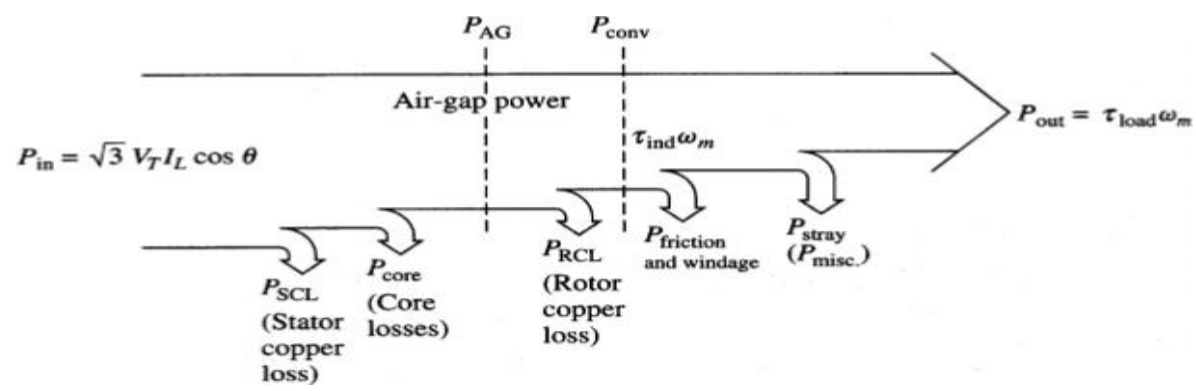

Gambar 4. Diagram Daya Berbeban Di Motor Induksi

- PSCL $\quad=\mathrm{I}^{2} \cdot \mathrm{R} 1$

- Pcore $\quad=\mathrm{E}^{2}$.Gc

- $\begin{aligned} & \text { PRCL }=\text { S.P. } \\ & \text { AG }\end{aligned}$

Keterangan:

- PSCL = Rugi-rugi pada stator

- Pcore = Rugi-rugi inti besi stator

- PRCL = Rugi-rugi pada rotor

- $\mathrm{PF} \& \mathrm{~W} \quad=$ Celah udara

- Pstray = Rugi-rugi yang tidak bisa di hitung

Jadi untuk menghitung berapa besaran daya keluaran pompa dapat dihitung dengan:

- Pin = Vpompa $\cdot$ Ipompa. $\cos \varphi$

- $\quad$ PAG

$=$ Pin - PSCL

- $\quad$ Pconv $=$ PAG - PRCL

- Prot

$=$ Pinnl $-P_{\mathrm{SCL}}$

- Pout

$=$ Pconv - Prot

Pout dapat dihitung dengan cara mengurangi Pin pada motor dengan rugi-rugi pada stator, motor, dan celah udara. Dimana Pin motor dan rugi-rugi pada motor sudah dapat dihitung.

\subsection{Menghitung Efisiensi Daya Motor}

Merupakan bentuk proses untuk mengetahui nilai efisiensi dari motor induksi dengan cara mencari nilai Pout motor yang dibagi dengan nilai Pin motor dan di kalikan dengan 100\%, setelah itu kita dapat mengetahui efisiensi motor.

$$
n_{\text {motor }}=\text { Pout motor / Pin motor X 100\% }
$$

\subsection{Mengetahui Besar efisiensi Penghematan Daya}

Untuk mengetahui besaran penghematan daya, dapat di cari dengan rumus:

$$
\text { Penghematan }=\frac{\text { Ptrottle-Pinverter }}{\text { Ptrottle }} \times 100 \%
$$




\section{Hasil Percobaan}

\subsection{Pengujian Motor Induksi 3 Fasa}

Pengujian motor induksi 3 fasa merupakan bentuk proses untuk mencari rangkaian ekivalen motor induksi 3 fasa, dengan melakukan pengujian DC, percobaan beban nol, dan percobaan hubung singkat.

Tabel 2. Pengujian DC

\begin{tabular}{|c|c|c|}
\hline $\mathrm{V}$ & $\mathbf{I}$ & $\mathbf{R}$ \\
\hline & & $7 \Omega$ \\
\hline
\end{tabular}

Tabel 3. Percobaan Beban Nol

\begin{tabular}{|c|c|c|c|c|c|c|c|c|}
\hline $\mathbf{V}_{\mathbf{L L}}$ & $\mathbf{V}_{\mathbf{R N}}$ & $\mathbf{V}_{\mathbf{S N}}$ & $\mathbf{V}_{\mathbf{T N}}$ & $\mathbf{V}_{\mathbf{L N}}$ & $\mathbf{I}(\mathbf{A})$ & $\mathbf{P}(\mathbf{w a t t})$ & $\mathbf{C o s} \boldsymbol{\emptyset}$ & $\mathbf{N}(\mathbf{R p m})$ \\
\hline 385 & 216 & 223 & 219 & 219 & 0,6 & 50 & 0,05 & 2996 \\
\hline
\end{tabular}

Tabel 4. Percobaan Hubung Singkat

\begin{tabular}{|c|c|c|c|c|c|c|c|}
\hline $\mathbf{V}_{\mathbf{L L}}$ & $\mathbf{V}_{\mathbf{R N}}$ & $\mathbf{V}_{\mathbf{S N}}$ & $\mathbf{V}_{\mathbf{T N}}$ & $\mathbf{V}_{\mathbf{L N}}$ & $\mathbf{I}(\mathbf{A})$ & $\mathbf{P}(\mathbf{w a t t})$ & $\mathbf{C o s} \boldsymbol{\emptyset}$ \\
\hline 62 & 40 & 40 & 40 & 40 & 1,4 & 60 & 0,5 \\
\hline
\end{tabular}

\subsection{Rangkaian Ekivalen Motor Induksi 1 Fasa}

Perhitungan ini bertujuan untuk mengetahui nilai dari parameter-parameter rangkaian ekivalen motor induksi 3 fasa.

$$
\begin{aligned}
& \mathrm{R}_{1}=13 \Omega \\
& R_{n l}=\frac{V_{n l^{2}}}{P_{n l}}=R_{n l}=\frac{219^{2}}{50 / 3}=2878,8[\Omega] \\
& Z_{n l}=\frac{V_{n l}}{I_{n l}}=\frac{219}{0,6}=365[\Omega] \\
& Z_{L R}=\frac{V_{L R}}{I_{L R}}=\frac{40}{1,4}=28,5 \mathrm{~V} \\
& Z_{n l}=365 \Omega \\
& Z_{L R}=R_{L R}+J X_{L R}=\left|Z_{L R}\right| \\
& \theta=\operatorname{Cos}^{-1} x \frac{P_{i n} \theta+J\left|Z_{L R}\right| \sin \theta}{3 V_{T} \times I_{L}}=\operatorname{Cos}^{-1} x \frac{75,1}{3.40 .1,4} \\
& =\operatorname{Cos}^{-1} 0,44 \\
& =63,89^{\circ}
\end{aligned}
$$

Sehingga,

$$
\begin{aligned}
& R_{L R}=\left|Z_{L R}\right| \operatorname{Cos} \theta=28,5 \operatorname{Cos} 63,89^{\circ}=12,5 \Omega \\
& R_{L R}=R_{1}+R_{2} \\
& R_{2}=R_{L R}-R_{1}=12,5-7=5,5 \Omega \\
& \text { Maka diperoleh } \\
& X_{L R}=\left|Z_{L R}\right| \operatorname{Sin} \theta \\
& \quad=28,5 \operatorname{Sin} 63,89^{\circ}=25,6 \Omega
\end{aligned}
$$

Motor Induksi 3 Fasa

$$
\begin{aligned}
X_{1} & =0,4 X_{L R}=0,4 \cdot(25,6)=10,24 \Omega \\
X_{2} & =0,6 X_{L R}=0,6 \cdot(25,6)=15,36 \Omega \\
Z_{n l} & =X_{1}+X_{m} \\
365 & =10,24+X_{m} \\
X_{m} & =365-10,24=354,7 \Omega \\
R c & =2878,8 \Omega
\end{aligned}
$$

Dari perhitungan, didapatkan data hasil pada Table 5: 
Tabel 5. Parameter Rangkaian Ekivalen

\begin{tabular}{|c|c|}
\hline Parameter & Nilai \\
\hline $\mathrm{R}_{1}$ & $7 \Omega$ \\
\hline $\mathrm{R}_{2}$ & $5,5 \Omega$ \\
\hline $\mathrm{X}_{1}$ & $10,24 \Omega$ \\
\hline $\mathrm{X}_{2}$ & $15,36 \Omega$ \\
\hline $\mathrm{X}_{\mathrm{m}}$ & $354,76 \Omega$ \\
\hline $\mathrm{R}_{\mathrm{C}}$ & $2878,8 \Omega$ \\
\hline
\end{tabular}

Dengan mengetahui parameter-parameter pada motor induksi dapat digambarkan rangkaian pengganti perfasa motor induksi 3 fasa pada Gambar 5:

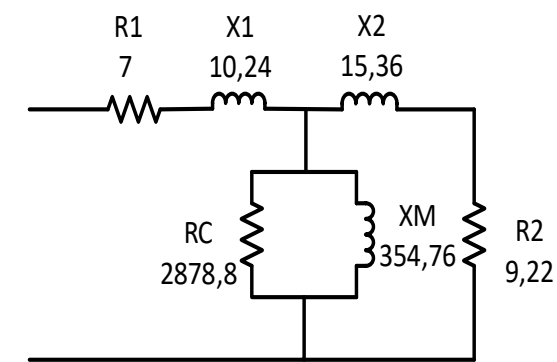

Gambar 5. Rangkaian Ekivalen Motor Induksi 3 Fasa

\subsection{Pengujian Torka}

Pengujian Torka menghasilkan nilai-nilai pada Tabel 6.

Tabel 6. Pengujian torka

\begin{tabular}{|l|l|l|l|l|l|l|l|l|l|}
\hline Throttle & \multicolumn{1}{l}{ Motor } \\
\hline $\mathbf{Q}(\mathbf{L} / \mathbf{m})$ & $\mathbf{V}_{\mathbf{L L}}$ & $\mathbf{V}_{\mathbf{R N}}$ & $\mathbf{V}_{\mathbf{S N}}$ & $\mathbf{V}_{\mathbf{T N}}$ & $\mathbf{V}_{\mathbf{L N}}$ & $\mathbf{I}(\mathbf{A})$ & $\mathbf{P}(\mathbf{W a t t})$ & $\mathbf{C o S} \boldsymbol{\emptyset}$ & $\mathbf{N}(\mathbf{r p m})$ \\
\hline 56,3 & 385 & 219 & 219 & 219 & 219 & 1,7 & 720 & 0,64 & 2890 \\
\hline 47 & 385 & 219 & 219 & 219 & 219 & 1,7 & 720 & 0,64 & 2885 \\
\hline 36 & 385 & 219 & 219 & 219 & 219 & 1,7 & 711 & 0,64 & 2883 \\
\hline 24 & 385 & 219 & 219 & 219 & 219 & 1,69 & 705 & 0,64 & 2882 \\
\hline 10 & 385 & 218 & 218 & 219 & 218 & 1,66 & 700 & 0,64 & 2882 \\
\hline
\end{tabular}

$\mathrm{X} 1 \mathrm{R} 1$

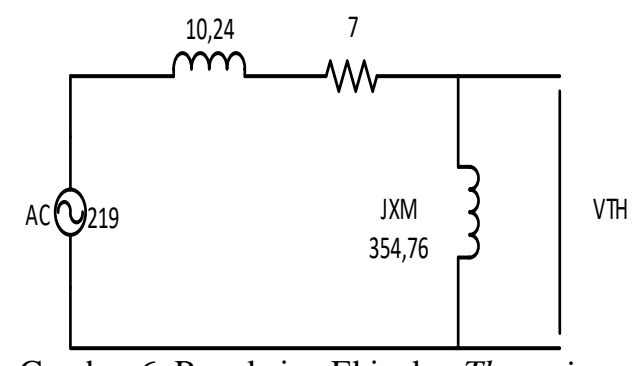

Gambar 6. Rangkaian Ekivalen Thevenin

Untuk mencari tegangan thevenin pada rangkaian Gambar 6, digunakan Rumus:

$$
V_{T H}=\frac{j X_{m}}{R_{1}+j X_{1}+j X_{m}} \cdot V_{\phi}=\quad V_{T H}=\frac{X_{m}}{\sqrt{R_{1}+j X_{1}+j X_{m}}} \cdot V_{\phi}
$$

Rangkaian thevenin adalah salah satu teori elektronika atau alat analisis yang menyederhanakan suatu rangkaian rumit menjadi suatu rangkaian sederhana dengan cara 
membuat suatu rangkaian pengganti yang berupa sumber tegangan yang dihubungkan secara seri dengan sebuah resistansi yang ekivalen.

$$
V_{T H}=\frac{354,76}{\sqrt{(7)^{2}+(10,24+354,76)^{2}}} \cdot 219=212,7 \mathrm{~V}
$$

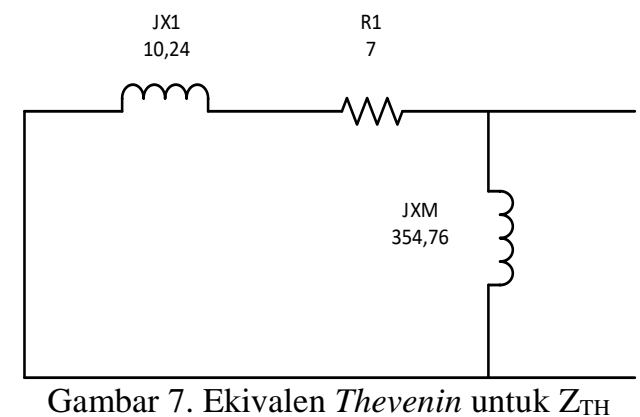

Untuk menghitung imepdansi thevenin pada rangkaian gambar 7, digunakan Rumus:

$$
\begin{aligned}
Z_{T H} & =\frac{j X_{m} \cdot\left(R_{1}+j X_{1}\right)}{R_{1}+j\left(X_{1}+X_{m}\right)} \\
& =\frac{j 354,76 \cdot(7+j 10,24)}{7+j(10,24+354,76)}=\frac{-3632+j 2483}{7+j 365}=6,6+j 10 \\
Z_{T H} & =R_{T H}+j X_{T H} \\
Z_{T H} & =6,6+j 10
\end{aligned}
$$

\section{Torka Induksi}

Torka induksi merupakan nilai torka motor pada saat motor induksi tidak berbeban.

$$
=\frac{3 \cdot(212,7)^{2} \cdot 5,5}{314 \cdot\left[(6,6+5,5)^{2}+(10+15,36)^{2}\right]}=3,01 N \text {. }
$$

\section{Torka Start}

Torka start merupakan nilai torka motor induksi pada saat starting awal dimana saat pengujian motor induksi tidak berbeban.

$$
=\frac{3 \cdot(212,7)^{2}}{2 \cdot(314)\left(6,6+\sqrt{(6,6)^{2}+(10+15,36)^{2}}\right)}=\frac{135723,8}{23881}=5,68 \mathrm{~N} . \mathrm{m}
$$

\section{Torka Maksimum}

Torka maksimum merupakan gaya puncak yang dibutuhkan motor induksi untuk menggerakan motor induksi pada saat motor induksi tidak berbeban, didapatlah nilai torka maksimum dari motor induksi.

$$
=\frac{3 \cdot(212,7)^{2}}{2 \cdot(314)\left(6,6+\sqrt{(6,6)^{2}+(10+15,36)^{2}}\right)}=\frac{135723,8}{23881}=5,68 \mathrm{~N} \cdot \mathrm{m}
$$

\subsection{Pengujian Motor Induksi Menggunakan Throttle}

Pengujian motor induksi menggunakan throttle merupakan bentuk pengujian motor induksi 3 fasa tanpa menggunakan inverter, pada pengujian ini kita melakukan pengaturan debit dengan cara mengatur Throttle yang terdapat pada pipa. 


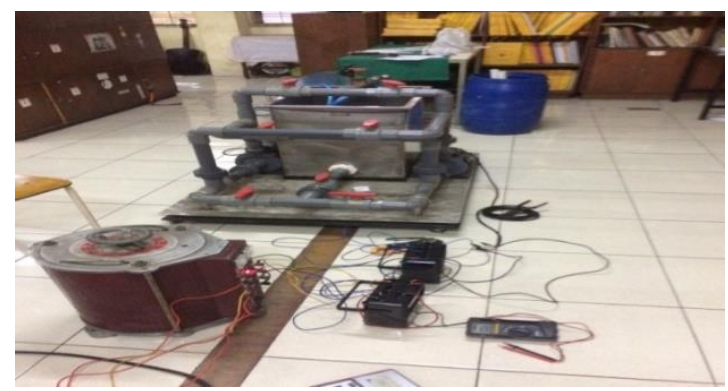

Gambar 8. Pengujian Motor Dengan Throttle

Tabel 8. Pengujian Motor Induksi

\begin{tabular}{|c|r|r|r|r|r|r|r|c|c|}
\hline Throttle & \multicolumn{9}{|c|}{ Motor } \\
\hline $\mathbf{Q}(\mathbf{L} / \mathbf{m})$ & $\mathbf{V}_{\mathbf{L L}}$ & $\mathbf{V}_{\mathbf{R N}}$ & $\mathbf{V}_{\mathbf{S N}}$ & $\mathbf{V}_{\mathbf{T N}}$ & $\mathbf{V}_{\mathbf{L N}}$ & $\mathbf{I}(\mathbf{A})$ & $\mathbf{P}(\mathbf{W a t t})$ & $\mathbf{C o s} \emptyset$ & $\mathbf{N}(\mathbf{r p m})$ \\
\hline 56 & 385 & 219 & 219 & 219 & 219 & 1,7 & 720 & 0,64 & 2890 \\
\hline 47 & 385 & 219 & 219 & 219 & 219 & 1,7 & 720 & 0,64 & 2885 \\
\hline 36 & 385 & 219 & 219 & 219 & 219 & 1,7 & 711 & 0,64 & 2883 \\
\hline 24 & 385 & 219 & 219 & 219 & 219 & 1,69 & 705 & 0,64 & 2882 \\
\hline 10 & 385 & 218 & 218 & 219 & 218 & 1,66 & 700 & 0,64 & 2882 \\
\hline
\end{tabular}

\section{Torka Beban}

Diberi pembebanan debit air $56 \mathrm{~L} / \mathrm{m}$

$$
\begin{aligned}
& n_{s}=\frac{120 \cdot f}{P}=\frac{120.50}{2}=3000 \mathrm{rpm} \\
& \text { Slip }_{\text {berbeban }}=\frac{n_{s}-n_{r}}{n_{s}} \times 100 \%=\frac{3000-2890}{3000} X 100 \%=0,036=3,6 \% \\
& \mathrm{P}_{\text {in }}=\sqrt{3} \cdot V \cdot I \cdot \operatorname{Cos} \varnothing \\
& =\sqrt{3} \cdot 385 \cdot 1,7 \cdot 0,64=725 \mathrm{~W} \\
& \mathrm{P}_{\mathrm{SCL}}=I_{1}^{2} \cdot \mathrm{R}_{1}=1,7^{2} .7 \quad=60,7 \mathrm{~W} \\
& \mathrm{P}_{\mathrm{AG}}=\mathrm{P}_{\text {in }}-\mathrm{P}_{\mathrm{SCL}}=725-60,7=664,3 \mathrm{~W} \\
& P_{\mathrm{RCL}}=\mathrm{S} . \mathrm{P}_{\mathrm{AG}} \quad=0,036.664,3=23,9 \mathrm{w} \\
& \mathrm{P}_{\text {conv }}=\mathrm{P}_{\mathrm{AG}}-\mathrm{P}_{\mathrm{RCL}}=664,3-23,9=640,4 \mathrm{~W} \\
& P_{\text {rot }}=P_{\text {innl }}-P_{\text {SCL }}=75-60,7=14,3 \mathrm{w} \\
& P_{\text {out }}=P_{\text {conv }}-P_{\text {rot }}=640,4-14,3=625,7 \mathrm{w} \\
& \omega_{\mathrm{s}}=\frac{2 \pi}{60} \times 3000=314 \mathrm{rad} / \mathrm{s} \\
& \omega_{m}=(1-s) \cdot \omega_{\text {sync }} \\
& =(1-0,036) \cdot 314=302,7 \mathrm{rad} / \mathrm{s} \\
& T_{\text {load }}=\frac{P_{\text {out }}}{\omega_{m}}=\frac{625,4}{302,7}=2,06 \mathrm{~N} . \mathrm{m} \\
& \eta=\frac{P_{\text {out }}}{P_{\text {in }}}=\frac{625,4}{725} \times 100 \%=86 \%
\end{aligned}
$$


Tabel 9. Hasil Percobaan Dalam 5 Kali Percoban Throttle

\begin{tabular}{|c|c|c|c|c|c|c|c|c|c|c|c|}
\hline \multicolumn{1}{|c|}{ Throttle } & \multicolumn{10}{|c|}{ Motor Induksi } \\
\hline $\boldsymbol{Q}(\mathbf{L} / \mathbf{m})$ & Pin & PSCL & P AG $_{\text {AG }}$ & P $_{\text {RCL }}$ & Pconv & P rot & Pout & Slip & $\omega_{m}$ & $T_{\text {load }}$ & $\eta$ \\
\hline 56 & 725 & 60,7 & 664,3 & 23,9 & 640,4 & 14,3 & 625,7 & $3,6 \%$ & 302,7 & 2,067 & $86 \%$ \\
\hline 47 & 725 & 60,7 & 664,3 & 25,23 & 639,07 & 14,3 & 625,4 & $3,8 \%$ & 302 & 2,066 & $86,2 \%$ \\
\hline 36 & 725 & 60,7 & 664,3 & 25,9 & 638,4 & 14,3 & 624,1 & $3,9 \%$ & 302,7 & 2,061 & $86 \%$ \\
\hline 24 & 721,25 & 60 & 665 & 25,93 & 639 & 15 & 624 & $3,9 \%$ & 301,7 & 2,067 & $86,5 \%$ \\
\hline 10 & 708,45 & 57,86 & 650,59 & 25,37 & 652,22 & 17,14 & 608,08 & $3,9 \%$ & 301,7 & 2,01 & $86,3 \%$ \\
\hline
\end{tabular}

\subsection{Pengujian Motor Menggunakan Inverter}

Tabel 10. hasil percobaan dengan inverter 5 kali percobaan

\begin{tabular}{|c|c|c|c|c|c|c|c|c|c|}
\hline \multicolumn{10}{|c|}{ Inverter } \\
\hline $\begin{array}{c}\boldsymbol{Q} \\
(\text { Debit })\end{array}$ & $\begin{array}{c}f \\
(\mathrm{~Hz})\end{array}$ & $\mathbf{V}$ & $\mathbf{I}(\mathbf{A})$ & $\begin{array}{c}\mathbf{P} \\
(\mathbf{w a t})\end{array}$ & $\begin{array}{c}\mathbf{N} \\
(\mathbf{r p m})\end{array}$ & $n_{s}$ & $\eta$ & Slip & $\begin{array}{c}\text { Torka } \\
(N . \mathrm{m})\end{array}$ \\
\hline 10 & 11 & 84,7 & 0,36 & 31 & 621 & 660 & $90,6 \%$ & $6,2 \%$ & 0,49 \\
\hline 24 & 22,6 & 174 & 0,78 & 148 & 1297 & 1356 & $96,9 \%$ & $3,9 \%$ & 1,07 \\
\hline 36 & 32,4 & 249,5 & 1,10 & 299 & 1841 & 1944 & $96,7 \%$ & $7,1 \%$ & 1,51 \\
\hline 47 & 42 & 323,4 & 1,46 & 509 & 2346 & 2500 & $95,75 \%$ & $5,8 \%$ & 2,01 \\
\hline 56 & 50 & 385 & 1,73 & 720 & 2813 & 3000 & $96 \%$ & $3,6 \%$ & 2,38 \\
\hline
\end{tabular}

\subsection{Penghematan Daya Pada Motor Pompa Menggunakan Inverter}

Perbandingan dan rata-rata penghematan daya menggunakan Throttle dan Inverter dapat dilihat pada Tabel 11.

Tabel 11. Perbandingan dan Rata-Rata Penghematan Daya Menggunakan Throttle dan Inverter

\begin{tabular}{|c|c|c|c|c|c|}
\hline \multicolumn{3}{|c|}{ Inverter } & \multicolumn{2}{c|}{ Throttle } & \multirow{2}{*}{$\begin{array}{c}\text { Penghematan } \\
\text { (watt) }\end{array}$} \\
\cline { 1 - 4 } $\boldsymbol{Q}$ (Debit) & $f$ & P(watt) & VLL & P(watt) & 669 \\
\hline 10 & $11 \mathrm{~Hz}$ & 31 & 385 & 700 & 557 \\
\hline 24 & 22,6 & 148 & 385 & 705 & 412 \\
\hline 36 & 32,4 & 299 & 385 & 711 & 211 \\
\hline 47 & $42 \mathrm{~Hz}$ & 509 & 385 & 720 & 0 \\
\hline 56,4 & $50 \mathrm{~Hz}$ & 720 & 385 & 720 & $\mathbf{3 6 9 , 8}$ \\
\hline \multicolumn{5}{|c|}{ Rata-Rata } \\
\hline
\end{tabular}

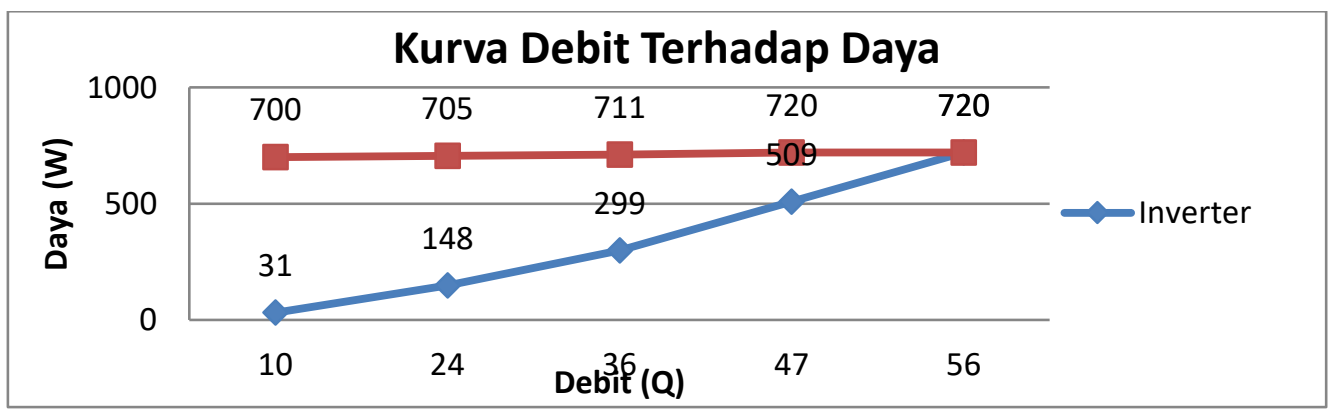

Gambar 9. Karakteristik Kurva Penghematan Daya Terhadap Debit 
Penghematan Energi/thn = Penghematan $/ \mathrm{bln} .12 \mathrm{bln}$

$=53,97 \mathrm{kWh} / \mathrm{bln} .12 \mathrm{bln}$

$=665,64 \mathrm{kWh} / \mathrm{thn}$

Pada hasil perhitungan nilai penghematan penggunbaan daya di dalam setahun adalah $665,64 \mathrm{kWh} / \mathrm{thn}$.

Tabel 13. Efisiensi Penghematan Daya

\begin{tabular}{|c|c|c|c|c|c|}
\hline \multicolumn{3}{|c|}{ Inverter } & \multicolumn{2}{c|}{ Throttle } & \multirow{2}{*}{$\begin{array}{c}\text { Efisiensi } \\
\text { Penghematan }\end{array}$} \\
\hline \multirow{2}{*}{ (Debit) } & $f$ & P(watt) & VLL & P(watt) & $95 \%$ \\
\hline 10 & $11 \mathrm{~Hz}$ & 31 & 385 & 700 & $79 \%$ \\
\hline 24 & $22,6 \mathrm{~Hz}$ & 148 & 385 & 705 & $57,94 \%$ \\
\hline 46 & $32,4 \mathrm{~Hz}$ & 299 & 385 & 711 & $29,3 \%$ \\
\hline 56 & $42 \mathrm{~Hz}$ & 509 & 385 & 720 & - \\
\hline 56,4 & $50 \mathrm{~Hz}$ & 720 & 385 & 720 & $\mathbf{5 2 , 3 6 2 \%}$ \\
\hline
\end{tabular}

\section{Kesimpulan}

Peforma dari motor dipengaruhi oleh besaran beban yang diberikan kepada motor. Nilai dari perbedaannya memang tidak cukup signifikan dalam peralatan skala yang kecil tetapi akan sangat berpengaruh kepada peralatan-peralatan industri yang berskala cukup besar.

Dari selisih penggunaan daya pada saat menggunakan throttle dan inverter, didapat total penghematan daya dalam 5 jam operasi motor dalam sehari. Nilai penghematannya dalam hitungan hari adalah: 417,2W. Apabilan diasumsikan dalam setahun nilai penghematannya adalah: $750,96 \mathrm{kWh} / \mathrm{thn}$.

Dapat disimpulkan bahwa hasil efisiensi penghematan total dari percobaan adalah: 73,7\%, penggunaan inverter sangat efisien untuk penghematan energy, karena inverter dapat mengatur penggunaan daya.

\section{Daftar Pustaka}

[1]. Prasetya, Ria, Analisis Penghematan Energi Pada Pompa Fasum Menggunakan Variable Speed Drive, UGM, 2013

[2]. Chapman, Stephan J. Electric Machinery Fundamental, Singapura: McGraw Hill, 1985.

[3]. Schneider Electric, "Characteristic Variable Speed Drive". Training efisiensi energi.

[4]. Sularso Haruo Tahara, Pompa Dan Kompresor. Pemilihan, Pemakaian, Dan Pemeliharaan. Jakarta: Pradnya Paramitha. 1994

[5]. Robert W.FOX, Philip J. Pritchard, Alan T. McDonald. Intruduction to Fluid Mechanics, 8th edition. Oklahoma: John Wiley. 2011.

[6]. Iwan Abdul Malik, Analisis Penghematan Energi Motor Listrik di PT. Suprama Sidoarjo, Itenas, 2013

[7]. Waluyo, Alinda Novita Sari, Syahrial, Penurunan Rating Tegangan Berpasangan Dari 380vac Menjadi 120vac Dengan Melilit Ulang Belitan Stator Pada Motor Induksi 3 Fasa. Jurnal Reka Elkomika, 3(1), 2015, pp. 1-16.

[8]. Bambang Prio Hartono dan Eko Nurcahyo, Analisis Hemat Energi Pada Inverter Sebagai Pengatur Kecepatan Motor Induksi 3 Fasa, Jurnal Elektrika. 1(1), 2017, pp. 9-16. 